\title{
Technology of Laser Forming
}

Norbert Radek ${ }^{1}$, Jozef Meško ${ }^{2}$, Andrej Zrak ${ }^{2}$

${ }^{1}$ Faculty of Mechatronics and Mechanical Engineering, Kielce University of Technology, Aleja 1000-lacia Panstva Polskiego 7, 25-314 Kielce. Republic of Poland, Email: norrad@tu.kielce.pl

${ }^{2}$ Faculty of Mechanical Engineering, University of Žilina, Univerzitná 8215/1, 01026 Žilina. Slovak Republic. Email: jozef.mesko@fstroj.uniza.sk, andrejzrak@gmail.com

The presented article describes the unconventional technology - bending and forming by laser. This technology is alters the tension in the material, which subsequently change the shape of formed parts. Article also describes four mechanisms of deformation after the impact of the laser beam on the material: The first mechanism - mechanism of temperature gradient, the second mechanism - buckling mechanism, the third mechanism - pressing mechanism (Borten) and the fourth mechanism - mechanism of phase transition. The experimental part focuses on the metallographic evaluation of samples from three different areas of the laser micro forming. Article describes in detail the technological parameters used during the development of the experiment and includes a summary of results. Article contains images of the structures detected in the heat affected zone.

Keywords: Laser forming, laser bending, $\mathrm{CO}_{2}$ laser, carbon steel

\section{Acknowledgement}

This work was supported in part by the KEGA č. $054 \check{Z} U-4 / 2012$ and VEGA č. 1/0836/13.

\section{References}

[1] FRACKIEWICZ, H. (1993). Method of bending metal objects with an energy beam, United States Patent. nr. 5 719 374, United States of America

[2] KOŇÁR, R., MIČIAN, M. (2012). Numerical simulation of residual stresses and distortions in butt weld in simulation program Sysweld. In: Comunications: scientific letters of the University of Žilina. Vol. 14, No. 3. pp. 4954. ISSN 1335-4205. Žilina.

[3] LUKOVICS, I. MALACHOVÁ, M. (2007). Use of Laser in Engineering. In: Manufacturing Technology. Vol. 12. No. 13. pp. 26-31. ISSN 1213-2489

[4] NOVÁK, P., ŽMINDÁK, M., PELAGIĆ, Z. (2014). High-pressure pipelines repaired by steel sleeve and epoxy composition. In: Applied mechanics and materials. Vol. 486, pp. 181-188. ISSN 1660-9336.

[5] NOVÁK, P., MEŠKO, J., ŽMINDÁK, M. (2013). Finite element implementation of Multi-Pass Fillet Weld with Phase Changes. In: Manufacturing Technology Vol. 13, No.1. ISSN 1213-2489

[6] ŽMINDÁK, M. et all. (2012). Numerical simulation of contact stresses analysis with crack. In: Machine modeling and simulations 2012. pp. 321-330, Poznan, ISBN 978-83-923315-2-0

[7] PAUNOIU, V. et all. (2008). Laser Bending of Stainless Steel Sheet Metals. In: International Journal of Material Forming, Vol. 1, Issue 1. Springer-Verlag. ISSN 1960-6206

[8] KOŇÁR, R., MIČIAN, M., STRAŠKO, J. (2010). Numerical simulation of temperature fields in sysweld simulation programme. In: International journal of applied mechanics and engineering, Vol. 15, No. 2, pp. 423-431. ISSN 1425-1655

[9] MIČIETOVÁ, M., NESLUŠAN, M., ČILLÍKOVÁ, M. (2013). Influence of surface geometry and structure after non-conventional methods of parting on the following milling operations. In: Manufacturing technology, Vol. 13, No. 2, pp. 152-157. ISSN 1213-2489

[10] LUKOVICS, I., MALACHOVÁ, M. (2007). Use of Laser in Engineering. In: Manufacturing technology, Vol. 7, pp. 26-31. ISSN 1213-2489 